\title{
ENGLISH LEARNING SYSTEM IN ISLAMIC BOARDING SCHOOL
}

\author{
Ilham Nurjaman
}

Yayasan Pendidikan Sahida

Jl. Cibiru Hilir No 3 RT 01 RW 01 Kabupaten Bandung

Email: ilham_nurjaman@yahoo.com

\begin{abstract}
This research is describe the real description about English learning system in SMP Plus Al-Aqsho. This research uses qualitative research design This research intends to find out: (1) the English learning system in SMP Plus Al-Aqsha Islamic Boarding School, (2) the output of the teaching of English learning system in SMP Plus AlAqsha Islamic Boarding School, and (3) the supporting factors and obstacles in achieving the effectiveness of English learning system at SMP Plus Al-Aqsha Islamic Boarding School. In presenting the data, descriptive method is used in this research. Descriptive method is research method that tried to describe and interpret the object based on the real situation of that object. Techniques of collecting data in this research are observation, questionnaire, and interview. From the research, it can be concluded that with this system, the score or achievement index, expecially English subject, the students are able to comprehend the material so that they get score in average of students' score exceed the standar from KKM. The supporting factor in learning English is the additional English subject under curriculum of KMMI, while the obstacle is the congest schedule.
\end{abstract}

Keywords : English Learning, System, Islamic Boarding School

\begin{abstract}
Penelitian ini bermaksud menggambarkan yang sesunggubnya tentang sistem pembelajaran bahasa Inggris di SMP Plus Al- Aqsha. Penelitian ini menggunakan model penelitian kualitatif. Penelitian ini bertujuan mengungkap: (1) sistem pembelajaran bahasa Inggris di Pondok Pesantren SMP Plus Al-Aqsha, (2) output dari pengajaran sistem pembelajaran bahasa Inggris di Pondok Pesantren SMP Plus Al-Aqsha, dan (3) faktor pendukung dan penghambat dalam mencapai efektivitas sistem pembelajaran bahasa Inggris di Pondok. Pesantren SMP Plus AlAqsha. Penelitian ini menggunakan metode deskriptif. Metode deskriptif adalah metode penelitian yang mencoba menggambarkan dan menginterpretasikan objek berdasarkan situasi nyata objek. itu. Teknik pengumpulan data dalam penelitian ini adalab observasi, kuesioner, dan wawancara. Dari hasil penelitian, dapat disimpulkan babwa dengan sistem ini, nilai atau prestasi indeks, khususnya subjek bahasa Inggris atau siswa dapat memahami materi sebingga mereka mendapatkan skor dengan nilai rata-rata lebih dari standar dari KKM. Faktor pendukung dalam belajar bahasa Inggris adalah mata pelajaran Bahasa Inggris merupakan mata pelajaran tambahan di bawah kurikulum KMMI, sedangkan kendalanya adalah jadwal yang padat.
\end{abstract}

Keywords : Belajar Bahasa Inggris, Sistem, Pondok Pesantren 


\section{INTRODUCTION}

Islamic boarding school is a social institution of religious education for Muslims who want to explore religious sciences (Farchan \& Syarifudin 2005). Islamic boarding school is one of the Islamic institutions that well-known by its education quality and its superior in teaching language to its student. Islamic boarding school gives priority to foreign language learning especially Arabic and English (Kompasiana, 23 March 2010).

The learning system of Islamic boarding school is not only about attending the class every morning and leaving at mid-day, but also its students also learn about the value as the motto said "What you see, hear and feel is education". Learning language itself is not the matter of memorizing grammar and structure but how to practice the language itself. For this reason students in Islamic boarding school are obliged to stay in the dorm in the school area and speak English to immediately practice English in their daily life.

SMP plus AL-Aqsha is one of Islamic boarding school in West Java. The English learning system that conducted in SMP plus Al-Aqsha is quite different with other general junior high school. It follows the lead of Gontor Islamic Boarding School for its language learning system. SMP plus Al-Aqsha is also well-known by it strength to educate its students discipline, language, and Islamic value. This research will focus on the components of teaching learning process conducted in SMP Plus AL- Aqsha. The purposes of the research are to find out: 1) The English learning system in SMP Plus Al-Aqsha Islamic Boarding School; 2) The output of the teaching of English learning system in SMP Plus Al-Aqsha Islamic Boarding School; and 3) The supporting factors and obstacles in achieving the effectiveness of English learning system at SMP Plus Al-Aqsha Islamic Boarding School.

In presenting the data, descriptive method is used in this research. Descriptive method is research method that tried to describe and interpret the object based on the real situation of that object. Techniques of collecting data in this research are observation, questionnaire, and interview.

\section{ANALYSIS}

SMP Plus Al-Aqsha is an educational institution established in Jatinangor - Sumedang, its position is very strategic because it can be reached by public transportation all day long. It is situated at the west point of Sumedang Regency, or in the border of Bandung Regency and Sumedang Regency. SMP Plus AlAqsha is one of Islamic boarding school in West Java. The English learning system that conducted in SMP Plus Al-Aqsha is quite different with other junior high school in common. It leads Gontor Islamic Boarding School for its language learning system. SMP Plus Al-Aqsha is also well-known by its strength to educate its students discipline, language, and Islamic value.

The purposes of education of SMP Plus Al-Aqsha a specifically can be known through the motto of SMP Plus Al-Aqsha and the panca jiwa Pondok 
Modern Al-Aqsha. Motto of education SMP Plus Al-Aqsha; 1) Virtuous; 2) Able-Bodied; 3) Knowledge-able; 4) Creative thinking and dynamic.

While the Panca jiwa Pondok Modern Al-Aqsha itself is: 1) Sincerity; 2) Simplicity; 3) Independent; 4) Muslim Brotherhood; and 5) Freedom. Vision of SMP Plus Al - Aqsha is Being a Junior High School who excels competitively and in the aspect of science and religion in West Java in 2014. Based on the vision, the mission of which is always used as a reference for the management in the process of education and learning in SMP Plus Al - Aqsha is:

1. Education in a professional manner by integrating general knowledge and religious knowledge.

2. Education effectively and efficiently, as well as responsive to developments and changes.

3. Develop academic culture among teachers to achieve the advantage competitive in the era global.

4. Build and improve the working ethos of teachers and employees to achieve of education effective and efficient manner.

5. Improve the quality of learning and facilitate learners to achieve competency standards and competitive.

6. Build and manage academic administration system effectively and efficiently.

7. Establishing cooperation with other parties in order to develop educational and economic Pondok Modern Al - Aqsha.

8. Nurture, guide, and facilitate learners to pious, noble (karimah), able-bodied, have extensive knowledge, and be able to think creatively and dynamically.

SMP PLUS Aqsha is an educational institution based boarding, the facilities is an important requirement in support of education and the learning process in SMP Plus Al-Aqsha. Therefore efforts to establish and develop the existing facilities and infrastructure continue to be in line with the issues and developments that keep popping up from year to year. SMP Plus Al-Aqsha has 21 classrooms for teaching learning process. It consists of seven classrooms for first grade, seven classrooms for second grade and seven classrooms for third grade. Beside those rooms, it also has an office, head master's room, teachers ${ }^{6}$ room, library, mosque, toilet, language laboratory, teachers' dormitory, students ${ }^{6}$ dormitory, football field, badminton court, basketball court, sport hall, and parking area.

Condition environment this school is sufficient clean and orderly, just a little annoyed because SMP PLUS Aqsa is located near the highway, so the learning process a little disturbed by the sound of passing vehicles. SMP PLUS Aqsha is used for teaching and learning process takes place from the morning until evening, because SMP PLUS Aqsha has curriculum based on KMMI (Curriculum Pesantren).

While the infrastructure owned of SMP Plus Al-Aqsha in general as follows: 1) Cottage land area of $70008 \mathrm{~m} 2 \pm$; 2) 3 pieces of microscope; 3) Some 
equipment for the practice of biology/physics; 4) Set of bands equipment; 5) 25 units of computer; 6) 25 sets of tables and chairs teacher; 7) 1 set Lcd infokus; and 8) 1 piece wirelise.

The total number of teacher staffs of SMP Plus Al-Aqsha Jatinangor Sumedang are 45 persons. And the head master of SMP Plus Al-Aqsha is Mr. Drs. Apit Miftahudin. In order to know about condition of the teachers at SMP Plus Al-Aqsha Jatinangor Sumedang, it can be seen in the following table:

THE CONDITION OF TEACHERS AT SMP PLUS AL-AQSHA JATINANGOR SUMEDANG

\begin{tabular}{|c|c|c|}
\hline No & Nama Guru & Mata Pelajaran \\
\hline 1 & Drs. Apit Miftahudin & $\overline{\text { PAI }}$ \\
\hline 2 & Cecep Abdul Salam, S.Pd & Matematika \\
\hline 3 & Agus Sopyan, S.Ip & IPS Terpadu \\
\hline 4 & Moch. Saidiman, S.T & IPA Terpadu \\
\hline 5 & Apip Hadisusanto, S.HI & PPKN \\
\hline 6 & Oih Baihaki, S.Pt & Matematika \\
\hline 7 & Samsudin, S.Pd & Olahraga \\
\hline 8 & Asep Awalluddin, S.HI & Bahasa Inggris \\
\hline 9 & Jajang Rahmat, S.Sos.I & Bahasa Sunda \\
\hline 10 & Anita Puspitasari, S.Pd & IPA terpadu \\
\hline 11 & Nani Suwarni, S.Pd & Bahasa Indonesia \\
\hline 12 & Hendri Final & Seni Budaya \\
\hline 13 & Neneng Sarifah H, S.Ag & Bahasa Indonesia \\
\hline 14 & Dulhadi S.Pd & IPA Terpadu \\
\hline 15 & Dewi Sri Mulyati, S.Ag & PPKN \\
\hline 16 & Neneng Rosmiati, S.Pd & Bahasa Inggris \\
\hline 17 & Dewi Fauziyyah, S.Sos & IPS Terpadu \\
\hline 18 & Jenal Mutakin & Bahasa Sunda \\
\hline 19 & Asoh, S. Ag & Bahasa Indonesia \\
\hline 20 & Wati Juwita, S.Pd. & Olahraga \\
\hline 21 & Royani, S.Pd.I & PAI \\
\hline 22 & Gungun Gunawan, S.Sos.I & IPS Terpadu \\
\hline 23 & Pera Herawati., S.Pd. & Seni Budaya \\
\hline 24 & Jenal Mutakin & TIK \\
\hline 25 & Agung Salinggih, M.Pd. & TIK \\
\hline 26 & Filly Hevilla Zen, S.Pd. & IPS Terpadu \\
\hline 27 & Ida Farida, S.Pd.I & Bahasa Sunda \\
\hline 28 & Yeni Siti Solihah, S.Pd.I & PAI \\
\hline 29 & Momo, S.HI. & IPS Terpadu \\
\hline 30 & Filly Hevilla Zen, S.Pd. & IPA Terpadu \\
\hline 31 & Cecep Saepudyen & Seni Budaya \\
\hline 32 & Heru Fitriansyah & TIK \\
\hline 33 & Dadang Kurnia, S.HI & PPKN \\
\hline 34 & Atep Nirwana, S.S. & Bahasa Indonesia \\
\hline
\end{tabular}




\begin{tabular}{|c|l|l|}
\hline No & \multicolumn{1}{|c|}{ Nama Guru } & \multicolumn{1}{c|}{ Mata Pelajaran } \\
\hline 35 & Erlina Siti Latifah, S.Pd. & Bahasa Inggris \\
\hline 36 & Abdullah Fihri, S.Pd. & Matematika \\
\hline 37 & Risca Purni, S.Pd. & Matematika \\
\hline 38 & Hani Rahmaliani Solihah, S.Pd. & Bahasa Inggris \\
\hline 39 & Ai Yeni Yulianti, S.Pd. & Bahasa Inggris \\
\hline 40 & Eli Suhaeli, S.Pd.I & Kaligrafi \\
\hline 41 & Jenal Mutakin & TIK \\
\hline 42 & Heru Fitriansyah & TIK \\
\hline 43 & Dewi Atiqah K, S.Pd.I & Bahasa Arab \\
\hline 44 & Herman Taryana & Bahasa Arab \\
\hline 45 & Dewi Sri Mulyati, S.Ag & Bahasa Arab \\
\hline
\end{tabular}

(School's document, 2013).

Beside the list of teachers above, there are also teachers of KMMI and salafi. They are alumnus of Pondok Modern Gontor and its branches, alumnus of Pondok Pesantren Sukamanah Tasikmalaya, alumnus of Pondok Pesantren Baitussalam Sukabumi, and alumnus of Pondok Pesantren An-Nur Garut.

THE CONDITION OF TEACHERS KMMI AT SMP PLUS AL-AQSHA JATINANGOR SUMEDANG

\begin{tabular}{|c|l|l|}
\hline No & \multicolumn{1}{|c|}{ Nama } & \multicolumn{1}{c|}{ Mata Pelajaran } \\
\hline 1 & Herman Taryana & Bahasa. Arab \\
\hline 2 & Ida Farida, S.Pd.I & Nahwu \\
\hline 3 & Royani, S.Pd. & Muthalaah \\
\hline 4 & Jenal Mutakin & Sharaf \\
\hline 5 & Jajang Rahmat, S.Sos. I & Tafsir \\
\hline 6 & Asep Awalludin, S.HI. & Kaligrafi \& Figh \\
\hline 7 & Heru Fitriansyah & Sharaf \\
\hline 8 & Ema Rahmawati & Kaligrafi \\
\hline 9 & Ahmad Suhaelli & Hadits \\
\hline 10 & Acep Andi Suhendi & Bhs. Inggris \& English \\
\hline 11 & Drs. Abdullah S, M.Ag & Fiqh \\
\hline 12 & Drs. Arief Rahman & Tafsir \\
\hline 13 & Diki Zakaria S.Sos.I & English Contextual \\
\hline 14 & Mualif & Nahwu \\
\hline 15 & Totoh & Ilmu Hadits \\
\hline 16 & Dewi Atiqah, S.Pd.I & Bahasa Arab \\
\hline 17 & Wina Sodikin & Insya \\
\hline 18 & Kahfi Fajar Abdullah & Muthalaah \\
\hline 19 & Yosa Nathalia & Insya \\
\hline 20 & Sandra Nursyahidah & English Contextual \\
\hline 21 & Hani Rahmaliani & Conversation \\
\hline 22 & Irfa Rizke Anisa & Mahfudzot \\
\hline 23 & Momo, S.HI. & Figh \\
\hline 24 & Ai Yeni Yulianti & Nahwu \\
\hline & & \\
\hline
\end{tabular}




\begin{tabular}{|l|l|l|}
\hline No & \multicolumn{1}{|c|}{ Nama } & \multicolumn{1}{c|}{ Mata Pelajaran } \\
\hline 25 & Imas Adidah & Tafsir \\
\hline 26 & Abdullah Fihri & Imla \\
\hline 27 & Hindasyah & Mahfudzot \\
\hline 28 & Ahsanudin & Mahfudzot \\
\hline
\end{tabular}

(School's document, 2013).

The number of students at SMP Plus Al-Aqsha Islamic Boarding School in academic 2013-2014 is 874 students. It consists of 452 males and 422 females. The number of students in this academic year increases from the former academic years. Those students come from different regions, such as Sumedang, Bandung, Tasikmalaya, Subang, Sukabumi, Jakarta, Bangka, Belitung, Sulawesi, and the other régions in West Java. All of the students stay in the dormitory which is available by the foundation. The condition of students at SMP Plus AlAqsha can be seen in the following table:

THE CONDITION OF STUDENTS AT SMP PLUS AL-AQSHA JATINANGOR SUMEDANG

\begin{tabular}{|c|c|c|c|c|}
\hline No & Class & Male & Female & Total \\
\hline 1 & VII & 161 & 152 & 313 \\
\hline 2 & VIII & 156 & 125 & 281 \\
\hline 3 & IX & 135 & 145 & 280 \\
\hline \multicolumn{2}{|c|}{ Total } & 452 & 422 & 874 \\
\hline
\end{tabular}

(School's document, 2013)

\section{English Learning System in SMP Plus Al-Aqsha}

SMP Plus Al-Aqsha is one of the educational institutions under the Guidance of Yayasan Al-Aqsha. As an educational institution, it requires good, creative, innovative, effective, and efficient quality management. It is done to make the management of institutions in SMP Plus Al-Aqsha run well, so that it can support the process of education and learning in it. Hence, unorganized and unsystematic institution management will negatively affect the survival and progress of SMP Plus Al-Aqsha itself in its various aspects. Realizing the importance of a good management institution as described above, the managers of SMP Plus Al-Aqsha strives to continue organizing, evaluating and performing a variety of improvements and innovations in the field of institutional SMP Plus Pondok Modern Al-Aqsha from year to year.

Changes in the institutional structure of SMP Plus Al-Aqsha were occur caused by a problem and the demands posed by the dynamics that occur in SMP Plus Al-Aqsha. For instance, the increasing number of students from year to year, increasing students' needs of some extra activities desired, the diversity of the curriculum and competencies to be achieved by this institution, and so forth. SMP Plus Al-Aqsha is a formal educational institution under educational 
institutions Pondok Modern Al-Aqsha. Therefore, the institutional of SMP Plus Al-Aqsha has the characteristics as a consequence of its existence as the spearhead of the realization of the educational program of Pondok Modern AlAqsha in general, that are mental and spiritual development, learning and mastery of science, religion and general knowledge, and parenting learners.

Qualification level of SMP Plus Al-Aqsha (Junior High School) is equal with SLTP. The equal level here does not mean the same, because the substance of SMP Plus Al-Aqsha contains two education systems, which are SMP (Junior High School) and KMMI (Kulliyat al-Muallimin wa al-Muallimat al-Islamiyah) that can be decoded by Islamic boarding school.

Curriculum is a set of plans and arrangements regarding the purposes, contents, and instructional materials, as well as the means used to guide the implementation of learning activities to achieve specific educational goals. It has been stated that the educational institutions run by Pondok Modern Al-Aqsha is SMP Plus Al-Aqsha, which the curriculum of SMP refers to the Indonesian Ministry of Education curriculum, while the curriculum of KMMI refers to the curriculum of Pondok Modern Gontor. Thus, one characteristic of SMP Plus Al-Aqsha is taught two sciences optimally, they are general science and religious science.

The curriculums applied in this school was KTSP from Indonesian Ministry of Education as well as the curriculum from Gontor, called KMMI (Kulliyat al-Muallimin wa al-Muallimat al-Islamiyah). Thus, all of Islamic books are obtained from Gontor, while the general textbooks are obtained from the publishers. The learning subjects based on KTSP Curriculum are as follow:

LEARNING SUBJECTS BASED ON KTSP CURRICULUM

\begin{tabular}{|c|l|c|l|}
\hline No & \multicolumn{1}{|c|}{ Mata Pelajaran } & No & \multicolumn{1}{|c|}{ Mata Pelajaran } \\
\hline 1 & Pendidikan Agama & 9 & Fisika \\
2 & Pendidikan Kewarganegaraan & 10 & Geografi \\
3 & Bahasa Sunda & 11 & PAI \\
4 & Bahasa Indonesia & 12 & Ilmu Ekonomi \\
5 & Bahasa Inggris & 13 & KTK \\
6 & Bahasa Arab & 14 & Sejarah \\
7 & Matematika & 15 & Pend Jasmani dan Kesehatan \\
8 & Biologi & 18 & TIK \\
\hline
\end{tabular}

(School's document, 2013)

The instruction at KMMI employs modern methods of teaching and makes innovations from time to time. The mediums of instruction are Arabic and English, except for a few subjects, which are taught in Indonesian. The institutional objectives of KMI are; 1) Societal orientation; 2) To lead a simple life; 3) To be unaffiliated with any political party; and 4) To seek knowledge for the sake of Allah. 
The educational aim of this pondok is to prepare capable Muslim leaders, scholars, educators and muballigh, who are spiritually and mentally balanced and who devote themselves to the development of the Muslimummah. This aim is based on the pondok's five principles, which are sincerity, simplicity, selfreliance, Islamic brotherhood and freedom. The spirit of life in this pondok, therefore, is based on these five principles. The teachers are highly dedicated and sincere, and they volunteer guidance, supervision, and give instruction to the students, while the students faithfully follow all instructions given by their teachers. Under the plain style of life, the students are trained to fulfill their own needs and necessities. In spite of the students' different tribes, cultures and even nations, they live in this pondok in the spirit of brotherhood. The subjects of KMMI are;

\section{LEARNING SUBJECTS BASED ON KMMI}

\begin{tabular}{|c|l|l|l|}
\hline No & \multicolumn{1}{|c|}{ Mata Pelajaran } & No & \multicolumn{1}{c|}{ Mata Pelajaran } \\
\hline 1 & Bahasa Arab & 10 & Nahwu \\
2 & Imla & 11 & Shorof \\
3 & Tajwid & 12 & Muthalaah \\
4 & Tafsir & 13 & Composition \\
5 & Hadits & 14 & Insya \\
6 & Fiqih & 15 & Exercise \\
7 & Ushuludin & 16 & Sejarah Peradaban Islam \\
8 & Mahfudzot & 17 & Kitab Ta'lim wa al-Mutaallim \\
9 & Kitab Akhlak al-Banin & 18 & Kitab Kaifitul marhaba \\
\hline
\end{tabular}

(School's document, 2013)

Besides, students of SMP Plus Al-Aqsha are claimed to speak Arabic and English actively. Educational period of SMP Plus Al-Aqsha is 3 years. In this junior high school, students have 2 report cards; SMP report cards and KMMI report cards. Besides, they also have two diplomas, one is from Indonesian Ministry of Education and the other one is from Pondok Modern Al-Aqsha.

To increase and strengthen students' ability, it is also held some additional language subjects. For instance, students have to follow Mufrodat subject (vocabulary) every morning. Then, in Wednesday morning, students have to make conversation in English or Arabic. Besides, students also have to follow four-language speech practice (English, Arabic, Indonesian and Sudanese) every Saturday night. Students also require two speak in two languages in their daily activities. This system of learning language is in line with the theory that say "Learning is a work process which is done by one to get a new behavior changes, as his experience result on interaction with their environment" (Slameto, 2003:2). 


\section{English Teaching Learning Process}

According to the interwiew with Head Master and English teachers, English teaching learning process in SMP Plus AL-Aqsha contains of two main activities, they are a learning process which follows the Ministry of Education which is held in a classroom, and a learning process which follows KMMI (Kulliyyat al-Mu'allimin wa al-Mu'allimat al-Islamiyat) which is held out of classroom.

Based on the observation that the writer conducted in class 7 B SMP Plus Al-Aqsha on 3 October 2013 the process of teaching learning in SMP Plus AlAqsha is the same with other junior high schools, either in the lesson plans or the syllables. The process of teaching learning which covers the four skills of English-listening, speaking, reading, and writing.

When an English teacher enter a classroom, the students are asked to stand up and give a greeting, then they have to pray together. After that, directly the teacher opens the teaching process in the way of repeating the last material that was taught in the last week, namely apperception. Before a new material is taught, previously the teacher gives some points or asks some questions related to the main material that will be taught in that meeting. In this stage of learning process, the teacher make the students to be active during the learning process by giving an image related to the material, then ask the students to guess what material will be taught by looking that image.

In giving the material, the teachers use Kurikulum Berorientasi Pengembangan Nilai Karakter Bangsa (KBPNKB), where in this activity; the students are able to have a critical and rational thinking. In this activity, the writer divides the study into four skills of English; a) listening; b) speaking; c) reading, and d) writing. In teaching listening skill, teacher uses a tape recorder to convey the material and by using speech method. An English teacher said that he tries making the students familiar with to listen a material. For the evaluation, the teacher repeats the material and followed continuously by students until they can comprehend what the teacher says. Besides the students study how to give a response for teacher's statement, they are also asked to pronounce some English word or sentence that the teacher says. The teacher also asks the students to have courage to speech in front of classroom in order to make them be familiar with speech activity in front of others. In the way of making them be familiar with speaking, the teacher gives a speech or conversation script to the students.

In teaching reading process, the teacher asks students to read a text which is related to material they taught. The way that is used to convey this skill, the teacher asks them to read the text one by one, then the teacher give a correction for their pronunciation and give a correct one for their wrong pronunciation. In teaching writing skill the teacher asks students to arrange some sentences, check off some word, and also make a composition related to the material. In this activity, the teacher tends to be active because there are some students still have some problems with the way to write composition. 
Before the teacher closes the learning process, the teacher repeats and give a conclusion about the taught-material and give some assignment as the matter for evaluation. A teacher adds that in order to gain the speaking assessment, the teacher always grade the students by seeing a quantity of vocabulary that they master when they speech in front of classroom.

\section{English Learning Process in KMMI}

\section{Daily Activity}

Vocabulary is one of the elements of the language that must be mastered by students in SMP Plus Al-Aqsa to get and easier communicate, because language is a set of basic a vocabulary. Basically, not all boarding schools are learning vocabulary, for it is essentially vocabulary learning in boarding school to implement the system of two languages, one of which there are in Islamic boarding school Al-Aqsha, where is implementing of education system in boarding school has two languages, namely: English Arabic and English, who practiced in everyday life. With the vocabulary learning can be add and multiply the vocabulary needed by students to speak in Arabic and English in their daily. There are many excess of in vocabulary learning system in pesantren Al-Aqsha includes; 1) Increase a vocabulary; 2) Make it easier for the students to translate a sentence; 3) Streamlining the students in speaking in a language (Arabic and English) which is done in the cottage to be applied in everyday life; 4) Those students can recite the vocabulary used in daily life properly.

Vocabulary is an important factor in all language teaching and of critical importance to the typical language learner. It is considerably large and also varies in number. No one can master all of the words of any language, but they can enrich the stock of words. The larger the vocabulary of the students, the more chance they have the ability of reading and writing. Therefore, it is the task of the English teacher to help their students improve their vocabulary along with grammar and pronunciation. Besides the daily learning process in classroom, the English learning process is also held on daily morning as long as 15 minutes. In this morning, each student has to memorize at least 15 words in English. They have to remember by saying those words, because they will get punishment if they don't do that. If they have mastered those 15 words, they will be given the other 5 words, and so on. This activity is called Morning Vocabulary.

\section{Weekly Activity}

a. Conversation

This conversation is held every Wednesday. This activity is called Morning Conversation. In this activity, each student is asked to make a conversation and practice it with their friends. This activity is under the guidance of Central Language Improvement (CLI). Every week CLI provide the certain theme. The Students should make a conversation based on the theme provided. In the process, Students make a long line in front of their dormitory. They stand face to face with their own partner. The language section of each dormitory look 
around and supervise this activity in order to make sure that students make a conversation with their friends. With the system of conversation there is a lot of benefits that can be taken, namely to simplify and facilitate the students for using speaking language (Arabic and English) and also accustom themselves to speak the language fluently, as well as the courage of the students trained in talking with other people.

b. Speech Practice

Speech practice is held every Saturday night. Students are designed in groups with the variety of Class or grade. Every Group has their own place and contain of 25-30 students. Each Group should make their own structure (Chief, Secretary, and so on). All students are asked to make a speech script and to practice a speech in front of others. They make a presentation of their script by turns. Speech practice run at the school consists of three languages, namely Arabic, English, and Indonesian. The main goal of the speech practice is to print the students a mentally strong, able to speak in a dignified manner, and able to express ideas and ideas to the audience, as well as adding the ability to speak both in quantity and quality vocabulary.

The aim of daily and weekly activity is to practice and make students usual to communicate in English with another. These activities exist under the language Institution in Yayasan Al-Aqsha. For the curriculum of KMMI, there are also the syllabus and lesson plans. They are almost the same as the syllabus and lesson plans of KTSP curriculum. By the existing of this curriculum, it becomes one of supporting factors of English learning process of KTSP curriculum.

Here is the part of interview held by the writer: The writer: is it effective if the learning process uses two curriculums? The KMMI curriculum staff: Insya Allah it is effective, KMMI is the supporting of Indonesian Ministry of Education curriculum. Thus, the combination of those curriculums is like mutualism relationship in the meaning that it supports each other.

\section{Evaluation}

Evaluation is the most important in a learning system results at the schools, evaluation system in SMP Plus Al-Aqsha Al-Aqsa is basically the same with other school, but are so distinctive from other schools, that in no boarding school exam.so, in SMP Plus Al-Aqsha has two systems of evaluation, evaluation of school and boarding school.

In the learning process classroom, the teacher always evaluate the students each completed lesson. Based on the results of interviews with teachers: I always do an evaluation of the student by speaking assessment methods. Basically, English learning can be said to be maximal if the students is able to speak and understand to what teachers say. The Teacher is not only assessing students assessment based on their worksheet or examination but also from their daily conversation. Teacher can score whether it is good or bad from their daily 
conversation. Student's performance also being assessed.

\section{The factors of the teaching English learning system in Al-Aqsha}

\section{Output}

The result achieved by this school by using this learning system was in both academic and non-academic sectors. We can reach the level of regency or even province. Even in the national level, we can get the third champions of Math Championship. In the academic sector, our UN result can be competed with the other schools. Even last year, we got the third champion in UN among West Java private schools.

\section{ACADEMIC and NON-ACADEMIC ACHIEVEMENTS YEAR 2012-2013}

\begin{tabular}{|c|c|c|c|c|c|c|c|c|}
\hline NO & EKSKUL & INSTRUCTRE & CHAMPIONSHIP & $\begin{array}{c}\text { LEVELOF } \\
\text { REGION }\end{array}$ & PLACE & TIME & ACHIEVEMENT & YEAR \\
\hline 1 & Science & Dulhadi & Liga Fisika Nasional & National & Jogjakarta & $\begin{array}{c}09-10 \\
\text { November } \\
2012\end{array}$ & & 2012 \\
\hline 2 & Math & Oih Baihaqi & LCCM & Jawa Barat & Majalengka & $\begin{array}{c}\text { Sabtu, } 17 \\
\text { November } \\
2012 \\
\end{array}$ & & 2012 \\
\hline 3 & Qiro'at & Ust Taryana & Muharram Fest & $\begin{array}{c}\text { Kota } \\
\text { Bandung }\end{array}$ & Pusdai & $\begin{array}{c}\text { Jum'at, } 16 \\
\text { November } \\
2012\end{array}$ & $3^{\text {rd }}$ Champions & 2012 \\
\hline 4 & & & FLSS & \begin{tabular}{|c|} 
Se- \\
SUBRAYON \\
$1 \mathrm{Kab}$. \\
Sumedang
\end{tabular} & $\begin{array}{c}\text { SMPN } 1 \\
\text { Tanjungsari }\end{array}$ & $\begin{array}{c}\text { Kamis, } 20 \\
\text { Desember } \\
2012\end{array}$ & $\begin{array}{c}\text { Champions of } \\
\text { creating short story }\end{array}$ & 2012 \\
\hline 5 & Tahfidz & $\begin{array}{c}\text { Herman Taryana } \\
\text { \& M. Wahid }\end{array}$ & Pentas PAI & $\begin{array}{c}\text { Kab. } \\
\text { Sumedang }\end{array}$ & Sumedang & & $\begin{array}{c}2^{\text {nd }} \text { Champions of } \\
\text { Tahfidz Qur'an }\end{array}$ & 2013 \\
\hline 6 & & $\begin{array}{c}\text { Herman Taryana } \\
\text { \& M. Wahid }\end{array}$ & Pentas PAI & $\begin{array}{c}\text { Kab. } \\
\text { Sumedang }\end{array}$ & Sumedang & & $\begin{array}{c}1^{\text {st }} \text { Female } \\
\text { Champions of } \\
\text { MTQ }\end{array}$ & 2013 \\
\hline 7 & & $\begin{array}{c}\text { Herman Taryana } \\
\text { \& M. Wahid }\end{array}$ & Pentas PAI & $\begin{array}{c}\text { Kab. } \\
\text { Sumedang }\end{array}$ & Sumedang & & $\begin{array}{c}2^{\text {nd }} \text { Champions of } \\
\text { LCC }\end{array}$ & 2013 \\
\hline 8 & & $\begin{array}{c}\text { Herman Taryana } \\
\text { \& M. Wahid }\end{array}$ & Pentas PAI & $\begin{array}{c}\text { Kab. } \\
\text { Sumedang }\end{array}$ & Sumedang & & General Champions & 2013 \\
\hline 9 & & & LOSANIARA & $\begin{array}{c}\text { Se-Bandung } \\
\text { Raya }\end{array}$ & $\begin{array}{c}\text { SMP-SMA } \\
\text { Al-Biruni } \\
\end{array}$ & & $\begin{array}{c}2^{\text {nd }} \text { Champions of } \\
\text { creating comic }\end{array}$ & 2013 \\
\hline 10 & English & $\begin{array}{c}\text { Neneng } \\
\text {,Rosmiati, Asep, } \\
\text { Awalluddin } \\
\end{array}$ & LOSANIARA & $\begin{array}{c}\text { Se-Bandung } \\
\text { Raya }\end{array}$ & $\begin{array}{c}\text { SMP-SMA } \\
\text { Al-Biruni }\end{array}$ & & $\begin{array}{c}1^{\text {st }} \text { Champions of } \\
\text { Story Telling }\end{array}$ & 2013 \\
\hline 11 & English & $\begin{array}{c}\text { Neneng } \\
\text {,Rosmiati, Asep, } \\
\text { Awalluddin }\end{array}$ & LOSANIARA & $\begin{array}{c}\text { Se-Bandung } \\
\text { Raya }\end{array}$ & $\begin{array}{c}\text { SMP-SMA } \\
\text { Al-Biruni }\end{array}$ & & $\begin{array}{c}3^{\text {rd }} \text { Champions of } \\
\text { Story Telling }\end{array}$ & 2013 \\
\hline 12 & & & LOSANIARA & $\begin{array}{c}\text { Se-Bandung } \\
\text { Raya }\end{array}$ & $\begin{array}{c}\text { SMP-SMA } \\
\text { Al-Biruni }\end{array}$ & & $\begin{array}{c}3^{\text {rd }} \text { Champions of } \\
\text { creating and reading } \\
\text { poem }\end{array}$ & 2013 \\
\hline 13 & Football & $\begin{array}{c}\text { Dede } \\
\text { Sihabudin }\end{array}$ & $\begin{array}{l}\text { LOSANIAR } \\
\text { A }\end{array}$ & $\begin{array}{c}\text { Se-Bandung } \\
\text { Raya }\end{array}$ & $\begin{array}{c}\text { SMP- } \\
\text { SMA } \\
\text { Al-Biruni }\end{array}$ & & $\begin{array}{c}1 \text { st } \\
\text { Champions } \\
\text { of Futsal }\end{array}$ & 2013 \\
\hline 14 & Nasyid & Momo & $\begin{array}{l}\text { LOSANIAR } \\
\text { A }\end{array}$ & $\begin{array}{c}\text { Se-Bandung } \\
\text { Raya }\end{array}$ & $\begin{array}{c}\text { SMP- } \\
\text { SMA } \\
\text { Al-Biruni }\end{array}$ & & $\begin{array}{c}\text { 1st } \\
\text { Champions } \\
\text { of Nasyid }\end{array}$ & 2013 \\
\hline 15 & $\mathrm{AMFC}$ & Oih Baihaqi & KLCCM & $\begin{array}{c}\text { Se-Jawa } \\
\text { Barat }\end{array}$ & $\begin{array}{l}\text { UIN } \\
\text { Bandung }\end{array}$ & $\begin{array}{r}\text { Selasa, } 09 \\
\text { April } 2013 \\
\end{array}$ & $\begin{array}{c}\text { 1st } \\
\text { Champions }\end{array}$ & 2013 \\
\hline
\end{tabular}


TABEL ACADEMIC and NON-ACADEMIC ACHIEVEMENTS

YEAR 2013-2014

\begin{tabular}{|c|c|c|c|c|c|c|c|c|}
\hline NO & EKSKUL & INSTRUCTRE & CHAMPIONSHIP & $\begin{array}{l}\text { LEVELOF } \\
\text { REGION }\end{array}$ & PLACE & TIME & ACHIEVEMENT & YEAR \\
\hline 1 & & $\begin{array}{c}\text { Herman Taryana } \\
\text { \& M. Wahid }\end{array}$ & Pentas PAI & Kab. Sumedang & Sumedang & & $\begin{array}{c}2^{\text {nd }} \text { Male Champions of } \\
\text { MTQ }\end{array}$ & 2013 \\
\hline 2 & Tahfidz & $\begin{array}{c}\text { Herman Taryana } \\
\text { \& M. Wahid } \\
\end{array}$ & Pentas PAI & Kab. Sumedang & Sumedang & & $\begin{array}{l}2^{\text {nd }} \text { Champions of } \\
\text { Tahfidz Qur'an }\end{array}$ & 2013 \\
\hline 3 & & $\begin{array}{c}\text { Herman Taryana } \\
\text { \& M. Wahid }\end{array}$ & Pentas PAI & Kab. Sumedang & Sumedang & & $\begin{array}{c}1^{\text {st }} \text { Female Champions } \\
\text { of MTQ }\end{array}$ & 2013 \\
\hline 4 & & $\begin{array}{c}\text { Herman Taryana } \\
\& \text { M. Wahid } \\
\end{array}$ & Pentas PAI & Kab. Sumedang & Sumedang & & $2^{\text {nd }}$ Champions of LCC & 2013 \\
\hline 5 & & $\begin{array}{c}\text { Herman Taryana } \\
\text { \& M. Wahid }\end{array}$ & Pentas PAI & Kab. Sumedang & Sumedang & & General Champions & 2013 \\
\hline 6 & & & LOSANIARA & $\begin{array}{c}\text { Se-Bandung } \\
\text { Raya }\end{array}$ & $\begin{array}{c}\text { SMP-SMA } \\
\text { Al-Biruni } \\
\end{array}$ & & $\begin{array}{l}2^{\text {nd }} \text { Champions of } \\
\text { creating comic }\end{array}$ & 2013 \\
\hline 7 & English & $\begin{array}{c}\text { Neneng } \\
\text { Rosmiati, Asep } \\
\text { Awalluddin }\end{array}$ & LOSANIARA & $\begin{array}{c}\text { Se-Bandung } \\
\text { Raya }\end{array}$ & $\begin{array}{c}\text { SMP-SMA } \\
\text { Al-Biruni }\end{array}$ & & $\begin{array}{c}1^{\text {st }} \text { Champions of Story } \\
\text { Telling }\end{array}$ & 2013 \\
\hline 8 & English & Asep Awalluddin & LOSANIARA & $\begin{array}{c}\text { Se-Bandung } \\
\text { Raya }\end{array}$ & $\begin{array}{c}\text { SMP-SMA } \\
\text { Al-Biruni } \\
\end{array}$ & & $\begin{array}{c}3^{\text {rd }} \text { Champions of } \\
\text { Story Telling }\end{array}$ & 2013 \\
\hline 9 & & & LOSANIARA & $\begin{array}{l}\text { Se-Bandung } \\
\text { Raya }\end{array}$ & $\begin{array}{c}\text { SMP-SMA } \\
\text { Al-Biruni }\end{array}$ & & $\begin{array}{c}3^{\text {rd }} \text { Champions of } \\
\text { creating and reading } \\
\text { poem }\end{array}$ & 2013 \\
\hline 10 & Football & Dede Sihabudin & LOSANIARA & $\begin{array}{c}\text { Se-Bandung } \\
\text { Raya }\end{array}$ & $\begin{array}{c}\text { SMP-SMA } \\
\text { Al-Biruni }\end{array}$ & & $\begin{array}{c}1^{\text {st }} \text { Champions of } \\
\text { Futsal }\end{array}$ & 2013 \\
\hline 11 & Nasyid & Momo & LOSANIARA & $\begin{array}{l}\text { Se-Bandung } \\
\text { Raya }\end{array}$ & $\begin{array}{c}\text { SMP-SMA } \\
\text { Al-Biruni }\end{array}$ & & $\begin{array}{c}1^{\text {st }} \text { Champions of } \\
\text { Nasyid }\end{array}$ & 2013 \\
\hline
\end{tabular}

(School's document, 2013)

The curriculum subdivision adds that the result is still not maximal yet because the students practice Arabic more than English, so their English practice is still not enough. But the curriculum always tries to make it maximal. As one of the success from the program of SMP Plus Al-Aqsha is seen by the increase of amount if interested person that want to enter this school. The raising interested students in this school caused by the view of society to the result of learning process; this case was stated by the head master. With this system, the score or achievement index, especially English subject, the students are able to comprehend the material so that they get score in average of students' score exceed the standard from KKM.

STUDENT SCORE

\begin{tabular}{|c|c|c|c|c|}
\hline \multirow{2}{*}{$\begin{array}{l}\text { PARTICIPANT } \\
\text { NUMBER }\end{array}$} & \multirow{2}{*}{$\begin{array}{l}\text { STUDENT } \\
\text { NUMBER }\end{array}$} & \multirow{2}{*}{$\begin{array}{l}\text { STUDENT } \\
\text { NAME }\end{array}$} & \multirow{2}{*}{$\frac{\text { ENGLISH }}{\text { KKM }}$} & LANGUAGE \\
\hline & & & & SCORE \\
\hline 1-11-02-25-344-011-6 & 11127001 & S 1 & 72 & 78 \\
\hline 1-11-02-01-358-108-5 & 11127002 & S 2 & 72 & 78 \\
\hline 1-11-02-10-803-008-9 & 11127003 & S 3 & 72 & 84 \\
\hline 1-11-02-25-347-004-5 & 11127004 & S 4 & 72 & 77 \\
\hline $1-11-02-25-347-005-4$ & 11127005 & S 5 & 72 & 78 \\
\hline 1-11-02-01-361-039-2 & 11127006 & S 6 & 72 & 77 \\
\hline $1-11-02-25-347-006-3$ & 11127007 & S 7 & 72 & 78 \\
\hline 1-11-02-01-389-026-7 & 11127009 & S 8 & 72 & 86 \\
\hline 1-11-02-21-050-040-9 & 11127010 & S 9 & 72 & 84 \\
\hline 1-11-13-03-023-038-3 & 11127011 & S 10 & 72 & 89 \\
\hline 1-11-02-01-439-009-8 & 11127012 & S 11 & 72 & 79 \\
\hline 1-11-02-25-347-009-8 & 11127013 & S 12 & 72 & 81 \\
\hline 1-11-02-11-805-006-3 & 11127014 & S 13 & 72 & 85 \\
\hline
\end{tabular}




\begin{tabular}{|c|c|c|c|c|}
\hline PARTICIPANT & STUDENT & STUDENT & ENGLISH & LANGUAGE \\
\hline NUMBER & NUMBER & NAME & KKM & SCORE \\
\hline 1-11-02-01-320-023-2 & 11127015 & S 14 & 72 & 87 \\
\hline $1-11-02-01-266-025-8$ & 11127016 & S 15 & 72 & 79 \\
\hline 1-11-02-22-070-049-8 & 11127017 & S 16 & 72 & 93 \\
\hline $1-11-02-40-330-006-3$ & 11127018 & S 17 & 72 & 81 \\
\hline 1-11-02-01-066-028-5 & 11127019 & S 18 & 72 & 85 \\
\hline 1-11-02-10-212-066-7 & 11127020 & S 19 & 72 & 80 \\
\hline $1-11-02-10-350-036-5$ & 11127021 & S 20 & 72 & 86 \\
\hline 1-11-02-01-361-041-8 & 11127022 & S 21 & 72 & 77 \\
\hline 1-11-02-25-309-099-6 & 11127023 & S 22 & 72 & 78 \\
\hline $1-11-02-25-358-025-8$ & 11127024 & S 23 & 72 & 86 \\
\hline $1-11-02-25-347-010-7$ & 11127025 & S 24 & 72 & 84 \\
\hline 1-11-02-19-317-008-9 & 11127028 & S 25 & 72 & 84 \\
\hline $1-11-02-25-358-010-7$ & 11127032 & S 26 & 72 & 86 \\
\hline 1-11-02-31-318-011-6 & 11127033 & S 27 & 72 & 89 \\
\hline $1-11-02-25-358-105-8$ & 11127034 & S 28 & 72 & 86 \\
\hline 1-11-02-01-361-057-8 & 11127035 & S 29 & 72 & 80 \\
\hline 1-11-02-17-730-071-2 & 11127037 & S 30 & 72 & 86 \\
\hline 1-11-02-01-364-112-9 & 11127038 & S 31 & 72 & 79 \\
\hline 1-11-02-01-374-026-7 & 11127039 & S 32 & 72 & 80 \\
\hline 1-11-02-25-358-117-4 & 11127041 & S 33 & 72 & 85 \\
\hline 1-11-02-01-174-024-9 & 11127043 & S 34 & 72 & 80 \\
\hline $1-11-02-25-324-021-4$ & 11127044 & S 35 & 72 & 82 \\
\hline 1-11-02-10-181-003-6 & 11127045 & S 36 & 72 & 89 \\
\hline
\end{tabular}

(School's document, 2013)

The student has achieve the score standard. By the system of learning that conducted in SMP Plus Al-Aqsha can be said that it is effective to increase students achievement of language competence. So, the writer can conclude that SMP Plus Al-Aqsha is an educational institution which is able to make performance students either from comprehending material case or contest case. This success was based on learning process that SMP Plus Al-Aqsha applies in maximal through two systems/curriculums.

\section{The Obstacles of Achieving the Effectiveness of English Learning System}

There are several difficulties that the school faced. In the conclusion the writer summarize that there are 3 point of difficulties: a) Policy. The first difficulties faced by the Al-Aqsha was from the law of government which is not the same with nowadays law. The school management and the teachers cannot firmly treat the misbehavior student. There are some limitation and regulation that overly indulgent the students. Previously, it is the school's policies how to treat the misbehavior students. For example in treating the students which does not obey the regulation of language. In the previous chapter the writer has been stated that the school required the students to use two languages in their daily activities based the weekly schedule (Arabic week or English week). But the head master adds that if there is a language infraction, the language institution has already prepared the vest of infraction. So if there is a student which does not speak English when in English day, they will be punished. By this rule 
students are inevitably use the language and indirectly used to speak either in English or in Arabic. In now day, this kind of regulation cannot be completely conducted by the school it collided with government regulation; b) Student Laziness. In other hand, an English teacher adds that one obstacle factors from their internal factor, that is the laziness of the student. Many Students are sleeping in the classroom when the teacher is delivering the material. Not only in the classroom, have students also showed their laziness in other activities; c) Students' Daily activities. Beside the factor above, there is also the other factor, which is the schedule of student's daily activities. The students start they day from $4 \mathrm{o}^{6} \mathrm{clock}$ in the morning and end it by $10 \mathrm{o}^{6} \mathrm{clock}$ in the evening. It is full activities which have to be done by students. Based on the observation result, the heavy schedule makes the students tired, and it becomes one of big obstacles in English learning system. Since, the students' time to take a rest is just a little. Besides, there are no holidays. Sunday is used to do KMMI activities. Based on the interview result, one of students said that the school system is good, but she wanted to have holiday in Sunday.

The full schedule of SMP Plus Al-Aqsha students are;

\section{SCHEDULE TIME STUDENTS PONDOK MODERN AL-AQSHA}

\begin{tabular}{|c|c|l|l|}
\hline No & Time & \multicolumn{1}{|c|}{ Activity } & \multicolumn{1}{|c|}{ Exp } \\
\hline 1 & $04.00-04.15$ & Get up and prepare Shubuh Prayer & Guide \\
2 & $04.15-04.50$ & Shubuh Prayer and read the Holy Qu'an & Mosque \\
3 & $04.50-05.00$ & Back to dormitory & Language Institution \\
4 & $05.00-05.15$ & Morning Vocabularies & Field \\
5 & $05.15-06.00$ & Sport & \\
6 & $06.00-06.30$ & Bath & \\
7 & $06.30-06.50$ & Breakfast & Class \\
8 & $07.00-07.40$ & Learning activity of KMMI & Class \\
9 & $07.40-09.20$ & Learning activity & Mosque \\
10 & $09.20-09.40$ & Dhuha Prayer & Class \\
11 & $09.40-11.50$ & Learning activity & Mosque \\
12 & $11.50-12.15$ & Dzuhur Prayer & Canteen \\
13 & $12.15-13.10$ & Lunch & \\
14 & $13.10-14.20$ & Learning activity & \\
15 & $14.20-15.00$ & Learning activity of KMMI & \\
16 & $15.00-15.10$ & Prepare to Ashar Prayer & Mosque \\
17 & $15.10-15.40$ & Ashar Prayer & Dormitory \\
18 & $15.40-16.00$ & Prepare & Class \\
19 & $16.00-17.10$ & Ekstra Kurikuler & \\
20 & $17.10-17.30$ & Bath & Mosque \\
21 & $17.30-17.45$ & Read the holy Qur'an & Mosque \\
22 & $17.45-18.20$ & Maghrib Prayer & Dormitory \\
23 & $18.20-19.00$ & Diner & \\
\hline
\end{tabular}




\begin{tabular}{|c|c|c|c|}
\hline No & Time & Activity & Exp \\
\hline 24 & $19.00-19.10$ & Prepare for Isya Praying & Dormitory \\
\hline 25 & $19.10-19.40$ & Isya Praying & Mosque \\
\hline 26 & $19.40-20.00$ & Prepare & Dormitory \\
\hline 27 & $20.00-21.00$ & Learning together & Class \\
\hline 28 & $21.00-21.20$ & Break & \\
\hline 29 & $\begin{array}{c}21.20-21.30 \\
-\end{array}$ & Wudlu & Dormitory \\
\hline 30 & $21.30 \quad 21.45$ & Absensi and Guidance & \\
\hline 31 & $21.45 \quad-$ & Resting and Sleeping & Dormitory \\
\hline
\end{tabular}

Thus, one obstacle from learning system is students' consciousness which still does not grow up in following the rules in SMP Plus Al-Aqsha.

\section{Supporting Factors of Achieving the Effectiveness of English Learning System}

1. Competent Teachers

The first supporting factor of achieving the effectiveness of English Learning System is the teachers. Most of the teachers SMP Plus Al-Aqsha are graduated from Darussalam Islamic Boarding school. This boarding school is known with its superior to educate its students with language competencies. These teachers are creating the good environments for the students to learn language. This can motivate and support students to use language in their daily activities.

2. Supporting Activities

The other supporting factors are Activities. The school management has already served some activities that can follow by students. A morning vocabulary, Weekly Speech Presentation and Friday Conversation is the most valuable activities that can improve students language competencies. In managing these activities, school management has form the language Institution or called Central Language Improvement. This division id responsibly for arranging some activities in improving student's ability in language.

3. Full-day school system

SMP Plus Al-Aqsha required it's students to stay in dormitory. This system of education can simplify the school to monitor students. In the case of supporting factor, the head master stated; One of the supporting factors is that the learning management becomes easier, for example, the activities of additional subjects. Beside the supporting factors, we also find some obstacles. For instance, the students stay in in the dormitory. Many of them are not comfortable, especially the first grade students. Thus, the first grade students are not much burdened during three first months. Based on observation, the supporting factor is because the tool and infrastructure in this school are good, so are the supporting factors for language, the students can directly practice the 
conversation once a week which is guided by the language institution. Besides, the are many English daily sentences put in the walls of the classes. It can be used in students' daily conversation. Then, there is also a language laboratory in the school. It is often used by students to learn both English and Arabic using its facilities. The other supporting factor is that students can work in group if they have any homework's, because they stay in the dormitory together.

\section{CONCLUSION}

This research finds that qualification level of SMP Plus Al-Aqsha (Junior High School) is equal with SLTP. The equal level here does not mean the same, because the substance of SMP Plus Al-Aqsha contains two education systems, which are SMP (Junior High School) and KMMI (Kulliyat al-Muallimin wa alMuallimat al-Islamiyab) that can be decoded by Islamic boarding school. The process of teaching learning in SMP Plus Al-Aqsha is the same with other junior high schools, either in the lesson plans or the syllables. The process of teaching learning which covers the four skills of English-listening, speaking, reading, and writing. It is added by the activities held under the curriculum of KMMI, such as English conversation, English vocabulary and speech practice. With this system, the score or achievement index, expecially English subject, the students are able to comprehend the material so that they get score in average of students' score exceed the standar from KKM. From the research, it also can be concluded that the supporting factor in learning English is the additional English subject under curriculum of KMMI, while the obstacle is the congest schedule. From the result above, the writer suggests A teacher must be very clever to motivate students to study hard, to decrease the laziness of students. Time is very important for student to learn. School have to re-arrange the students schedule to not make them too tired.

\section{REFERENCES}

Alwasilah, A. Chaedar. 1993. Linguistike Suatu Pengantar. Bandung: Angkasa Anwar, Ali. 2011. Pembaruan Pendidikan di Pesantren Lirboyo Kediri. Yogyakarta: Pustaka Pelajar.

Arikunto, Suharsimi. 1998. Prosedur Penelitian Suatu Pendekatan Praktek. Jakarta: Bumi Angkasa.

Brown, H. Douglas. 1994. Teaching by Principles: An Interactive Approach to Language Pedagogy. New Jersey: Prantice Hall Regents.

Broughton, Geoffrey. 2003. Teaching English as a Foreign Language second edition. New York: Rutledge.

David Steven \& Mike fleming.2010. English Teaching in the Secondary School Linking theory and practice. New York: Routlage.

Dubin-Elite Olshtein, Freida. 1986. Course Design; Developing Program and Materials for Language Learning. Cambridge: Cambridge University Press. Harmer, Jeremy. 2007. How to teach English. New York: Longman. 


\section{Longman.}

1991. The Practice of English Language Teaching. New York:

Kusuma, Deden Cahaya. 2013. Analisis Komponen-Komponen Pengembangan Kurikulum 2013 pada Bahan Uji Publike Kurikulum 2013. Jurnal Analisis Komponen-Komponen Pengembangan Kurikulum. Bandung

Petrus, Ismail. 2012. A Portrait of the English Course at a Faculty of Education in Sumatera. Indonesian Journal of Applied Linguistics, Vol. 1 No. 2 (January 2012). CONAPLIN JOURNAL

Richards, Jack C \& Theodore S Rodgers. 2006. Approaches and Methods in Language Teaching. Cambridge: Cambridge University Press.

Subagja, Soleh. 2010. Gagasan Liberalisasi Pendidikan Islam. Jawa Timur: Madani.

White, Ronald V. 1988. The Elt Curriculum; Design, Innovation and Management. New York: Basil Blackwell. 